\title{
COMPETENCE APPROACH: IDENTIFICATION OF SPECIALIST'S PROFILE BY INTERNATIONAL MULTIDISCIPLINARY TEAM
}

Article describes competence approach in the system of higher education which was implemented within elaboration of innovative training courses for human resources and region sustainable development. Development and implementation of innovative methodology, based on psychological mechanisms of selfcognition as a cognitive basis for self-development and self-realisation, is presented. It is dictated by the needs to overcome imbalance between existing and necessary resources relative to requirements of modern society and labour market in a period of dynamic transformations. Aims of experimental research were identification and formation of the ideal profile of a modern specialist in the field of sustainable region development who was able to act as so-called "agent of changes". During the experiment data were collected with the help of specially developed questionnaires. On the basis of these questionnaires the comparative analysis of European and Ukrainian professional approaches to the "ideal profile" of the modern specialist in the field of sustainable development was carried out. It is emphasized the significant role of self-cognition as cognitive component for detailed professional and personal identification. Special attention is given to the profiles' formation by international multidisciplinary teams from European and Ukrainian universities. The teams identified modern Bachelor, Master, Postgraduate and lifelong learning student profiles concerning requested generic, professional and specific research competencies in the sphere of sustainable development. It should be noted that scientists, experts, professors, teachers, researchers as well as managers, heads of industrial enterprises, specialists in the field of international projects management and human resources, psychologists, sociologists were involved in activities of the multidisciplinary teams. Specially developed strategy, tools, team work methodology, questionnaires are presented in the article. Gained experience is applied for development of other training courses, curricula, learning materials.

Key words: self-cognition, evaluation, generic competencies, professional competencies, subject specific competencies related to research, specialist's ideal profile, human resources sustainable development, training of the trainers programmes.

Articulation of the problem. Problem of human resources (HR) development in line with European standards and requirements related to the integration into the European educational space is the urgent need of the modern international educational community. Ukraine is not an exception in this regard. Moreover, responsibility for the development of a qualified professional who is able to successful fast self-development in accordance with emerging requirements or needs, effective crisis management, problem solving, tasks arranging on the base of the most efficacious strategy, working in a team, leadership and self-realisation was assigned to Ukrainian High School. New paradigm of thinking formation, harmonic interaction of the young generation with the environment and society are the actual conditions of survival in current situation of socium, act as a guarantee of successful career and a harmonious existence in the environment.

We have often seen a situation when a university graduate found himself/herself far behind from the real urgent professional requirements, and had a lack of practical skills for task's realisation because he/she gained at the university a "baggage of knowledge" which was out of practical implementation and outdated. Unfortunately, the discrepancy between theory and practice, the presence of out-dated courses, disciplines, and teaching methods are not rare features of Ukrainian university education.

Aim of the article. The aim of the article includes analyse of the situation which causes subsequent problems with the employment of the university graduates. Many former students, who came to work in organizations and enterprises, did not have the slightest ideas "How can they start their practical activities?", "What is real state of the art in their professional sphere?"

The solving problem of this discrepancy is the aim of our practical research. The main tasks of this article are both to show real practical implementation of the competence approach in the professional sphere and use of self-cognition and self-realisation methodologies in the personal development and human resources development. The development of strategies, instruments, surveys and questionnaires is the practical aim of the research presented by international multidisciplinary team in this article.

Discourse of the article. Participation in the international projects within EU scheme has helped us to solve the described problem on the base of psychological research and implemented competence-based approach for personal student's 
and HR development within real project activities devoted to elaboration of the innovative training courses.

The methodology was based on the principles of self-cognition situation modelling in the conditions of everyday life and university training described by Natalya Turlakova [1, c. 48-50]. Psychological mechanisms helped to define the gaps between real and ideal situations, evaluated personal resources and society requirements, chose the optimal training strategy according to personal senses and needs $[1$, c. $51-54]$.

Teaching methods and training technology were based on the metacognitive approach described in EcoHumanistic Technology of Self-Development - EHTSD developed by Tatiana Sergeyeva. EHTSD aimed at shaping the student's personality as a proactive agent of positive changes through the development of his/ her senses, behaviour and morals based on eco-humanistic principles. Purposeful personality development was carried out within the limits of its uniqueness on the basis of reflection of individual experience, internal resources and personal senses in the context of actual professional, social and existential goals [2, c. 185].

Schemes overlaying technique was based on professor Sergeyeva's idea to impose personal cognitive schemes and compare them with the socially developed schemes [2, c. 288-298]. The concept of schemes overlaying helped us to identify the discrepancies between available and required knowledge and skills within practical professional sphere. The feedback was given in the format of schemes, profiles, tables and diagrams.

Detailed description of HR sustainable development within European projects was contributed to the training of the trainers' programme methodology developed by leading experts in the professional field. Thus, developed and realized methodology of HR sustainable development could be applied for solving different problem situations during transformation periods.

International projects were good polygons for approbation of the new methodology for sustainable HR development and realization of the competence approach in the process of innovative courses development. The experimental project was aimed at developing students of architectural specialities as future agents of the positive changes in the urban and regional development. Student's professional and personal development came from the process of concrete discipline mastering.

For identifying competence profile of the modern specialist in the field of architecture the project team, which consisted of theexpertsfrom CambridgeUniversity, Milan Polytechnics, Saragossa University, National Institute of Applied Science, Technological Educational Institute of Athens, Polytechnic Institute of Guarda, Varna Free University, Paris Association of Exchange \& Consulting in International Technologies, Kharkiv National University of Civil Engineering \& Architecture, Prydneprovska State Academy of Civil Engineering \&
Architecture, Kyiv National University of Construction \& Architecture, Lviv Institute of Architecture, Odessa State Academy of Civil Engineering \& Architecture, made analysis of modern labour market \& society needs and requirements in the context of city and region sustainable development. Group of methodologists developed the structured interview for experts in urban and region development both in practical \& academic fields and organized their interaction on the basis of brain storm technique. Metacognitive competence allowed converting training into self-developmental process that is directed, monitored and controlled by the person in accordance with individual aims, resources and conditions [3, c. 189-194].

A series of workshops and discussions were held. The experts - leading teachers from architectural departments, unions of architects, experts from design institutes, bureaus and practitioners from construction-engineering companies took part in these workshops. As a result "Problem tree" and "Object tree" were identified in the context of urgent needs in sustainable urban and region development. "Specialist's ideal profile" for student's development as well as "project team competences profile" for HR development was built in graphic form with descriptors of key competencies given in EcoHumanistic Technology. The strategic approach to student development was based on the idea of humanenvironment synergetic interaction [4, c. 53-55]. Meta-competencies required from modern specialist in the period of great transformations were given. Student played proactive role in self-development due to metacognitive approach that allowed converting everydayness into educational polygon.

Profiles could serve as tools:

1) for developing curricula for MSc, PhD, LLL;

2) for evaluation of curriculum efficiency based on comparison of ideal \& real profiles as well as profiles of experts in the professional sphere;

3) for evaluation of personal development: regular feedback provided by specially designed tools invested into self-control, self-evaluation and selfmanagement of the training process [5, c. 176-178]. Original technique of individual sense-cognitive schemes matching allowed not only visualize student zone of individual development but also measure it.

To make a bridge between EU and UA approaches it was decided to organize communication and sharing experience between Ukrainian course units' authors and European experts and university lecturers. The specially-developed questionnaire was sent to all developers of course units and experts. The questionnaire was devoted to identification of experience in the field of sustainable city and region development, existence of training materials, identification of the experience in the development and/or management of the LLL program in the universities, presentation of any experience in organizing e-learning, developing e-training material, distance learning or blended learning courses 
development, indication of existence of contacts with universities and organizations.

Kharkiv university methodologists' team made investigation in the field of competences identification. They selected, developed and summarized data obtained by European and Ukrainian experts in the format of interim tables describing generic, professional and research competences for MSc, PhD \& LLL students in USD. European and Ukrainian academicians, researchers, business, industrial and managerial experts from all participating organizations were proposed to range the competences using criteria of importance. Obtained data was summarized and analysed by methodologists' team with the help of computer programme. Feedback was given to European and Ukrainian experts and academicians in the format of final comparative tables colour -marking the most demanding generic, professional and research competences (see figures 1 ,
2, 3 below). The multidisciplinary international project team performed 6 functions corresponding to the roles of 1) project coordinators, 2) methodologist, 3) authors of training course units, 4) trainers, 5) evaluators, 6) IT experts. Every role implied competences for improvement within training at practical organizations and performance during training materials development. Integrating academic \& professional expertise the team was mobilized for overviewing existing curricula in the context of discovered "competence profiles" with qualification descriptors. It was decided to develop a computer program providing self-developing training resource by summarizing the scope of teaching materials available at all universities.

On the basis of the obtained results the training of the trainers program was developed. The key principles of training were providing optimal and proactive participants' activity based on their existential (everydayness) experience.

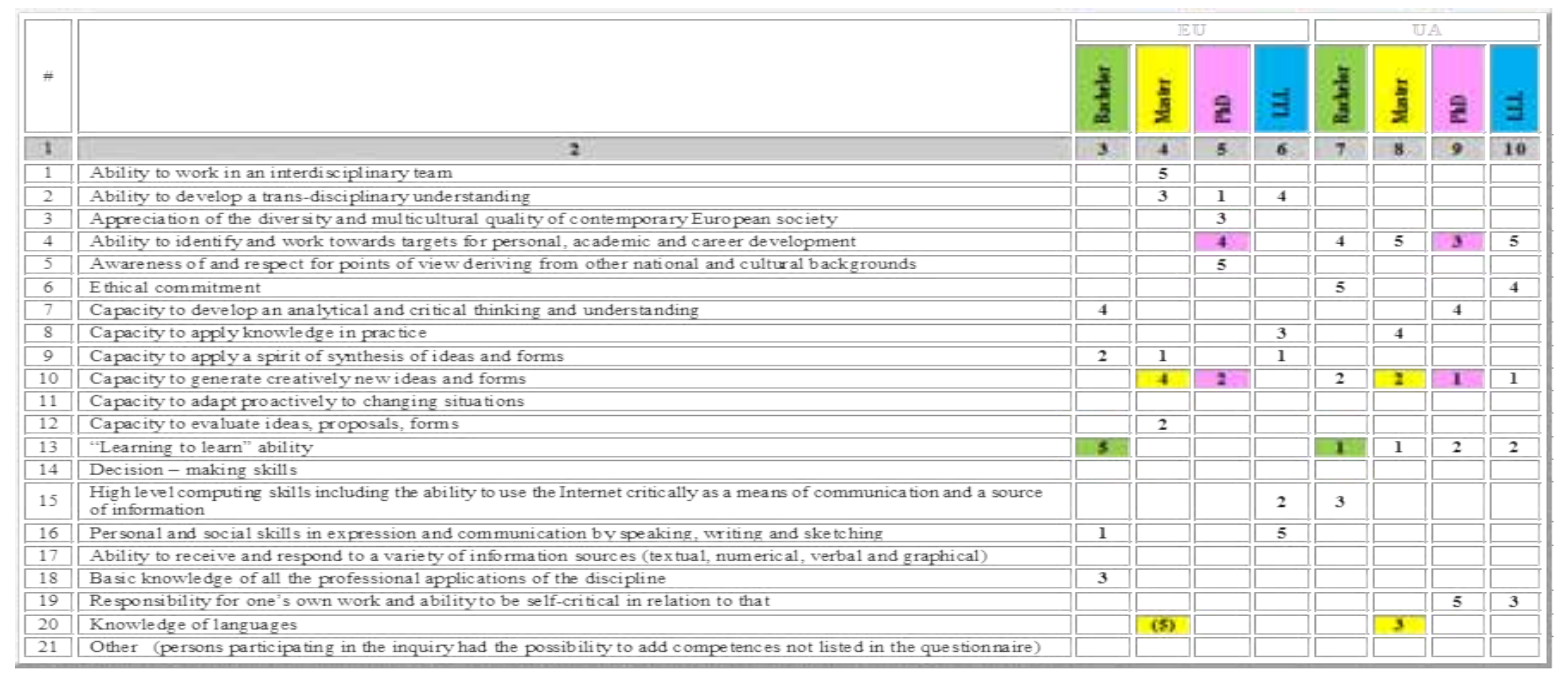

Fig. 1. Comparative analyses of generic competences

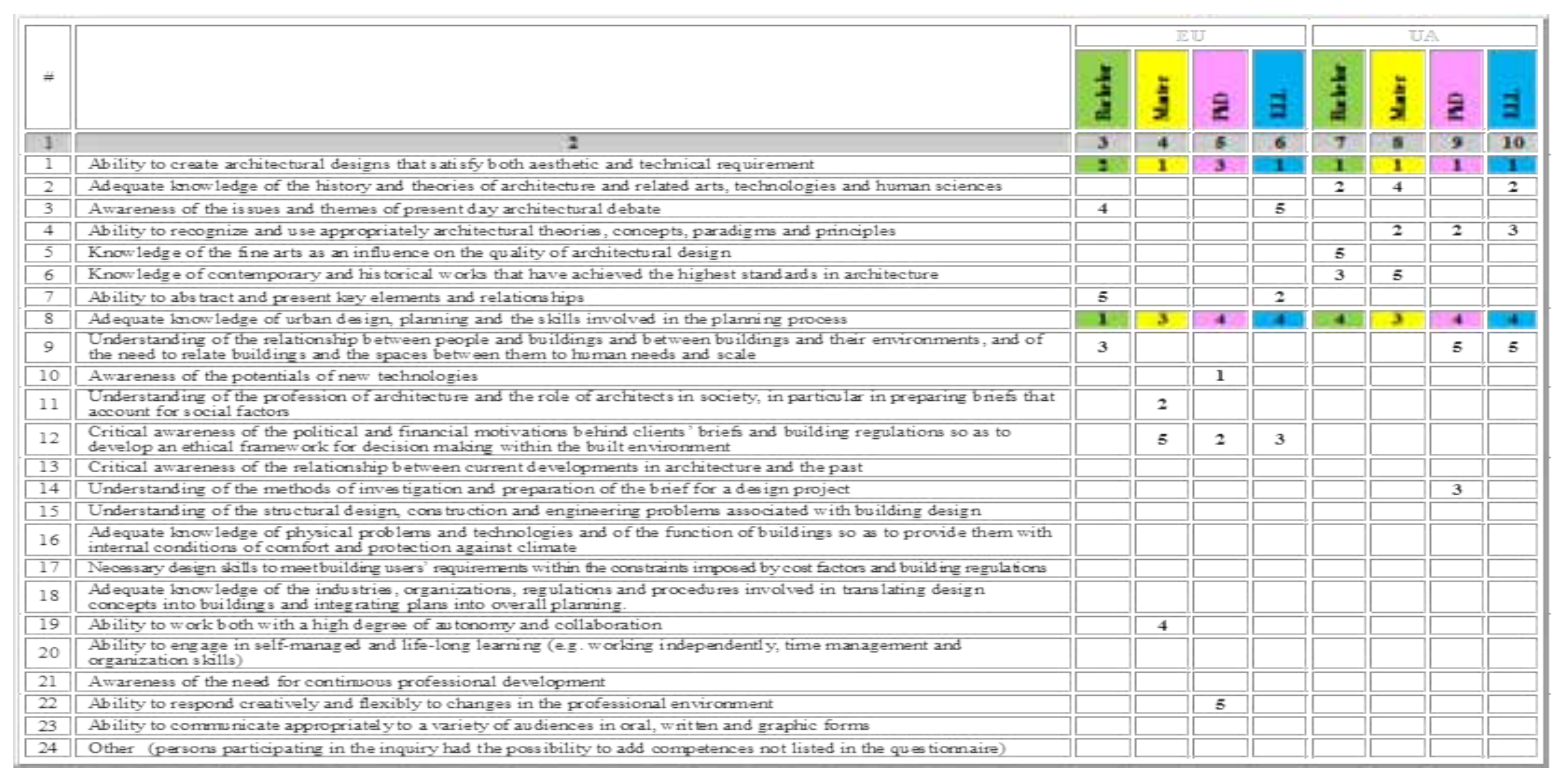

Fig. 2. Comparative analyses of professional competences 
ISSN 2663-6026 (Print), 2663-6034 (Online). Теорія і практика сучасної психології

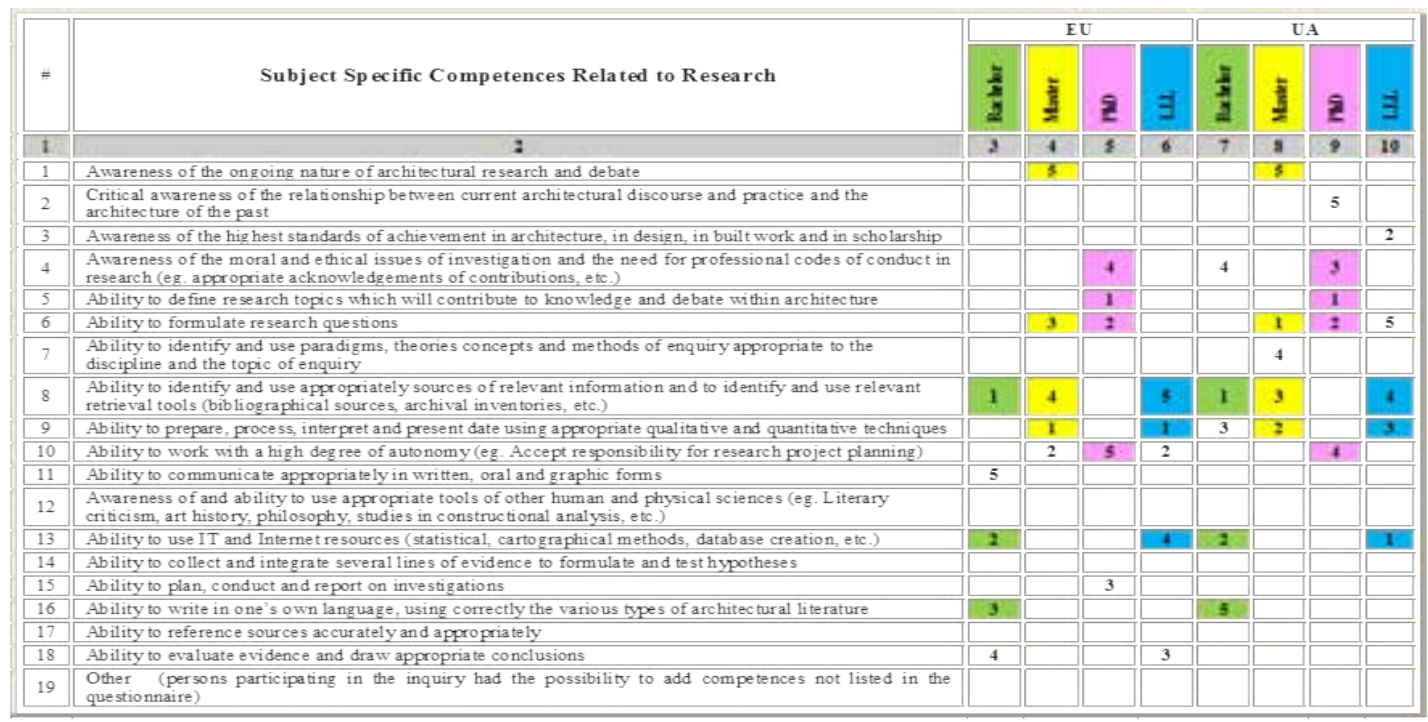

Fig. 3. Comparative analyses of research competences
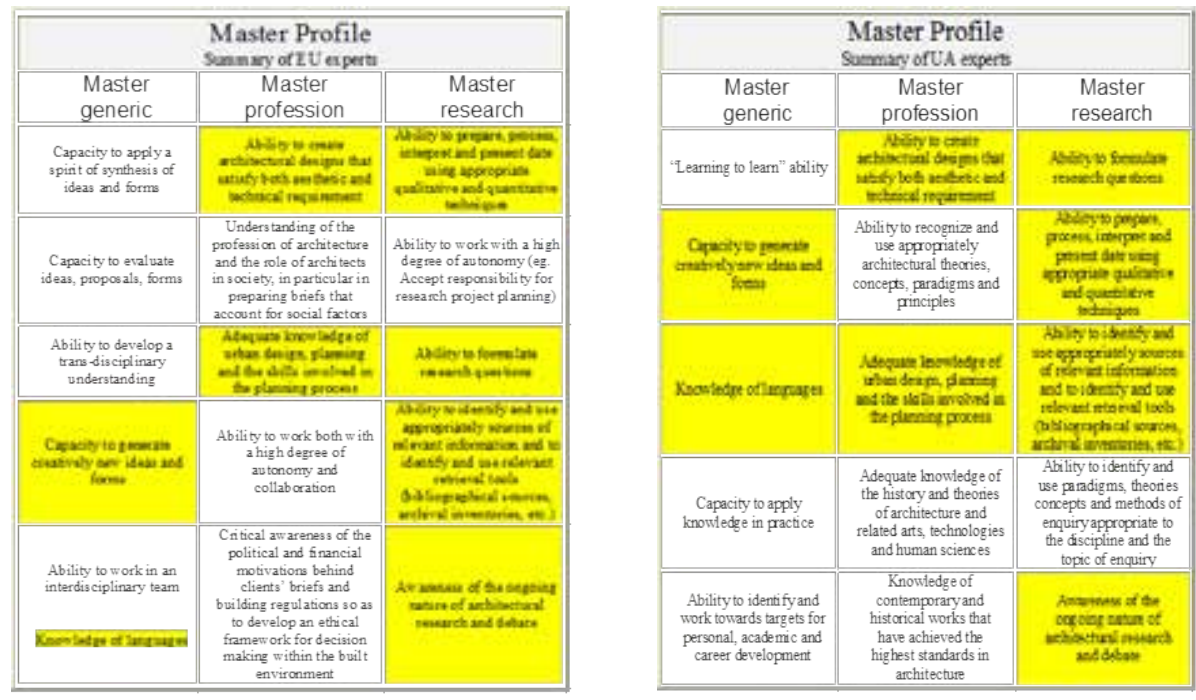

Fig. 4. Master Profiles: summary of EU and UA experts
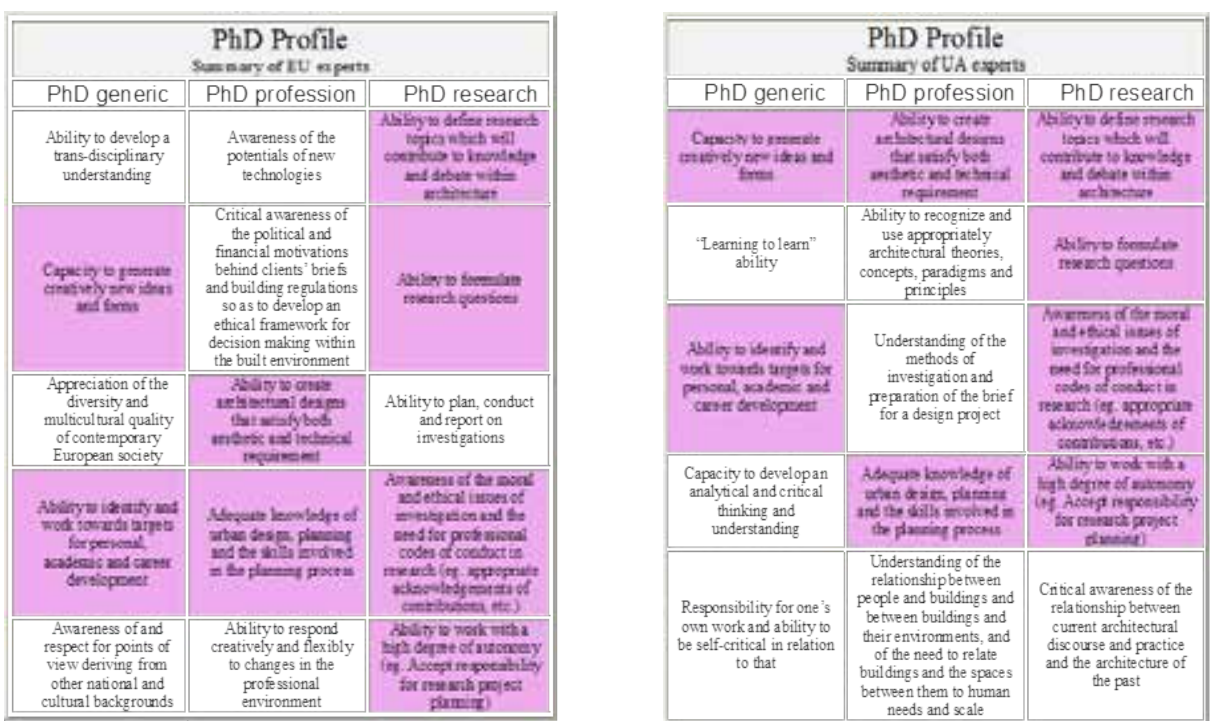

Fig. 5. PhD Profiles: summary of EU and UA experts 

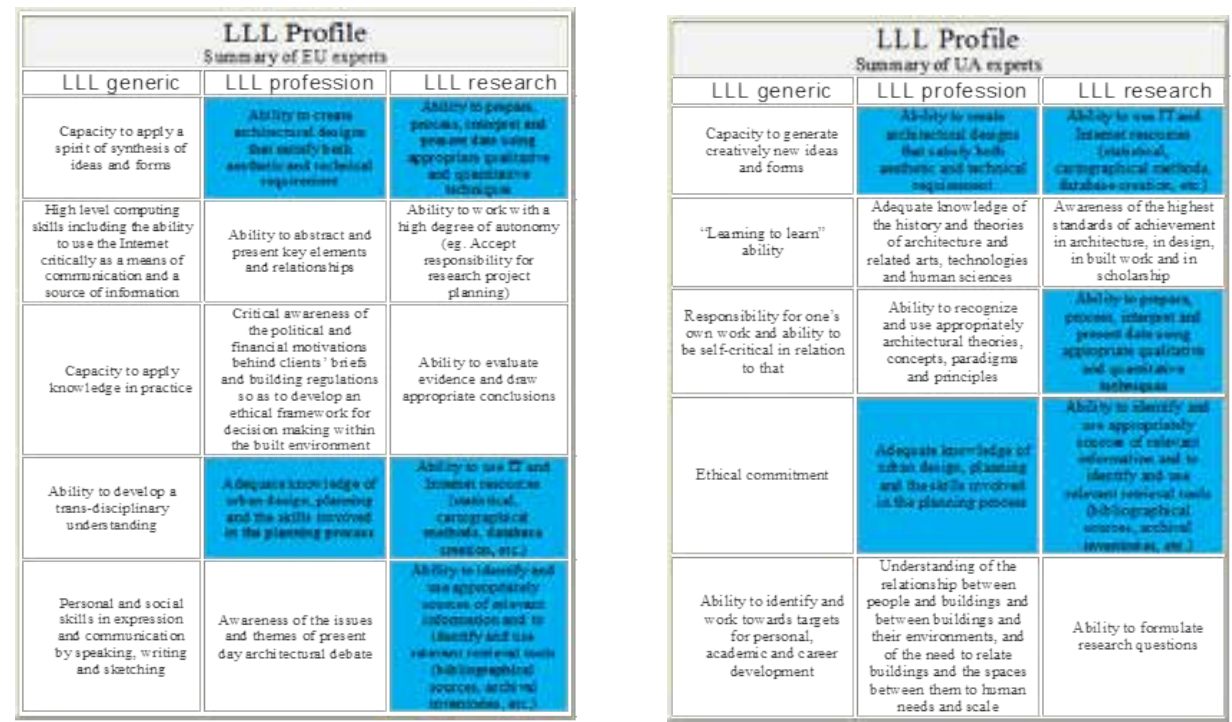

Fig. 6. LLL Profiles: summary of EU and UA experts

As a final result key competences were selected with the help of comparative analyses. Competence profiles for bachelor, master, postgraduate and LLL students were developed (see figure 4, figure 5, figure 6).

Gaps between European and Ukrainian profiles identified zones of the strategic development and collaborative methods. All results were also reflected in the format of evaluation reports which helped to analyse commonness and diversities. Students gained concrete practical training technologies which were based on their own cognitive and personal resources, senses, practical skills and professional environment requirements.

Comparative analysis of the identified profiles was useful for organizing dialogue between academicians, practitioners/employers and students for developing synergetic curriculum of sustainable HR development based on eco-humanistic principles.

The main activity was aimed at developing human resources by European program for training Ukrainian trainers using competence profiles. Innovative methodology provided strategy and tools for multidisciplinary multicultural dialogue and synergetic interaction based on competence approach and variety of modes for solving similar or common problems.

As a result of the activity aimed at personal and professional development of HR it was expected to develop "agents of positive changes" among students and improve Ukrainian universities staff by educators who were motivated for self, social \& educational environment development, ready to learn \& share, open to new experience, capable to develop innovative curricula, methodology \& e-resources.
Realized comparative analysis of the identified competence profiles (generic, professional and research) was used as a platform for organizing dialogue between European and Ukrainian specialists for developing synergetic interaction based on ecohumanistic principles of sustainable development.

\section{References:}

1. Турлакова Н.Б. Самопізнання як когнітивна основа саморозвитку особистості студента в умовах соціальних трансформацій : дис. ... канд. психол. наук : 19.00.07. Харків : ХНУБА, 2015. 205 c.

2. Сергеева Т.В. Эко-Гуманистическое саморазвитие. Харьков : АП «Блок», 2009. 547 с.

3. Сергеева Т.В. Метакогнитивные знания как когнитивная основа обучения и воспитания. Актуальні проблеми психології: зб. наук. праць Інституту психології ім. Г.С. Костюка НАПН України. T VI. Психологія обдарованості. Вип. 8. Житомир : Вид-во ЖДУ ім. І. Франка, 2012. 262 c. C. $187-196$

4. Сергеева Т.В. Эко-гуманистический подход к саморазвитию личности. Вісник Харківського національного університету ім. В.Н. Каразіна № 1009. Харків : ХНУ ім. Каразіна, 2012. Вип. 49. Серія «Психологія». С. 53-55.

5. Сергеєва Т.В., Турлакова Н.Б. Система зворотного зв'язку як засіб самоконтролю, самооцінки і самокерування в умовах навчання. Наукові записки Харківського військового университету : соціальна фрілософрія, педагогіка, психологія. Харків, 1999ж. Вип. V. C. $175-179$. 


\footnotetext{
Турлакова Н. Б. Компетентністний підхід: ідентифікація профілю спеціаліста міжнародною багатодисциплінарною командою

У статті описується компетентнісний підхід у системі вищої освіти, який був реалізований у рамках розроблення інноваційних навчальних курсів зі сталого розвитку людських ресурсів і регіонів. Описується розроблення та використання методології, яка була заснована на залученні психологічних механізмів самопізнання у якості когнітивної основи саморозвитку і самореалізації. Це було продиктовано нагальною потребою в подоланні дисбалансу між наявними і необхідними ресурсами щодо вимог сучасного суспільства та ринку праці в період динамічних транссрормацій. Метою експериментального дослідження були ідентифрікація і фрормування ідеального профрілю сучасного фахівия в галузі сталого розвитку регіонів, здатного виконувати фуункцію так званого «агента змін». Під час експерименту були зібрані дані за допомогою спеціально розроблених опитувальників, на основі яких проведено порівняльний аналіз європейських та українських професійних підходів до «ідеального профрілю» сучасного фрахівия в галузі сталого розвитку. У статті підкреслюється значна роль самопізнання як когнітивного компоненту під час визначення детальної професійної та особистісної ідентисрікації. Особлива увага приділяється процедурі визначення та будування профрілів міжнародними багатодисциплінарними командами з європейських та українських університетів. Команди визначали сучасні профрілі бакалавра, магістра, аспіранта та студентів LLL щодо необхідних загальних, профресійних та специфрічних науково-дослідницьких компетентностей у сфері сталого розвитку. Слід зазначити, що до роботи у складі багатодисциплінарних команд були залучені науковці, експерти, профресори, викладачі, дослідники, а також менеджери, керівники промислових підприємств, фахівці у сфрері управління міжнародними проектами та людськими ресурсами, психологи, соціологи. У статті також представлені спеціально розроблені стратегія, інструменти, методологія командної роботи, опитувальники та процедури ідентифрікації профрілів. Набутий досвід застосовується для розроблення інших навчальних курсів, навчальних програм та навчальних матеріалів.

Ключові слова: самопізнання, евалюації, загальні компетентності, профресійні компетентності, предметні компетентності, пов'язані з науковими дослідженнями, ідеальний профріль спеціаліста, сталий розвиток людських ресурсів, програми підготовки тих, хто навчає.
} 